\title{
Cell Structure and Quantitative Gram Stain of Bacillus megaterium
}

\author{
BY R. SCHERRER \\ Institute for Hygiene and Bacteriology, University of Basel, Basel, Switzerland
}

(Received 13 August 1962)

\begin{abstract}
SUMMARY
In a strain of Bacillus megaterium the Gram reaction was investigated by comparing its effect on intact bacilli with its effects on bacilli treated with lysozyme in several different ways. The lysozyme-treated bacteria varied from bacilli showing only polar separation of the cell wall from the protoplasm to protoplasts free from cell wall. The uptake of the primary dye (crystal violet) by intact bacteria was higher than that of all lysozymedepolymerized cell forms. Iodine uptake depended on the previous uptake of crystal violet. Therefore it was lower for the lysozyme-depolymerized forms. Cell wall took up crystal violet and iodine in small quantity. The same dye iodine complex was formed in all cell structures (cell wall and protoplasm). Gram differentiation was obtained with $95 \%(\mathrm{v} / \mathrm{v})$ ethanol in water, and this was found to extract much less of the dye iodine complex from intact bacteria than from the lysozyme-depolymerized

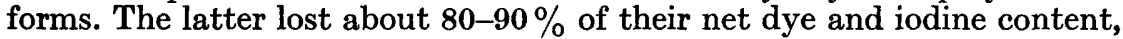
whereas intact bacilli lost only $20-45 \%$. This was due to the cell wall which formed a barrier to the ethanol extraction of the dye iodine complex, for organisms whose cell walls had been depolymerized or even dissolved by lysozyme during or after the iodine step of the Gram reaction lost much more dye and iodine than intact bacilli. Chemical integrity of the cell wall is a prerequisite for Gram positivity.
\end{abstract}

\section{INTRODUCTION}

Much new information on the mechanism of the Gram reaction has been obtained in the last 10 years by Gram staining bacterial suspensions. Several authors have studied the uptake of the primary dye (crystal violet) by Gram-positive and Gramnegative bacteria. Their results were divergent. Barbaro \& Kennedy (1954) and Wensinck \& Boevé (1957) analysed the complete Gram reaction of bacteria in suspension. Barbaro \& Kennedy (1954) considered that the difference in the uptake of the primary dye which was smaller for Gram-negative bacteria, played the most important role in the Gram differentiation. Wensinck \& Boevé (1957) found that the dye uptake was the same for Gram-positive and Gram-negative bacteria. In their view differentiation is obtained by the decolorization which extracts a small amount of dye iodine complex from Gram-positive bacteria and large amount from Gram-negative bacteria. Wensinck \& Boevé (1957) and Salton (1961) supposed that the cell wall played an important role in the Gram differentiation. Lysozyme, the enzyme which attacks only the cell wall of some bacterial species, transforms Grampositive bacteria into Gram-negative forms (Welshimer \& Robinow, 1949; Petronelli, 1950; Stähelin, 1953; Gerhardt, Vennes \& Britt, 1956). This reversal of the 
Gram reaction is one of the first signs of the action of lysozyme upon the bacterial structure (Scherrer, 1961). The present paper reports studies of the action of lysozyme on Bacillus M, a strain of Bacillus megaterium (Tomcsik 1950, 1960), and its influence on a quantitative Gram reaction, especially the role of the cell wall in the Gram reaction of the whole organism.

\section{METHODS}

Bacillus megaterium strain $\mathrm{N}$ was grown on nutrient agar for $13 \mathrm{hr}$. at $30^{\circ}$; suspensions of it were made in deionized water, in saline $(0.9 \%(\mathrm{w} / \mathrm{v}) \mathrm{NaCl})$ or Ringer solution. A standard suspension for each of the three types of suspension was obtained by measuring its turbidity (reading 300 of the Klett-Summerson colorimeter, filter 54).

Preparation of the 'lysozyme-depolymerized forms' of Bacillus м: Lysozyme (crystallized lysozyme; Mann Research Laboratories, Inc., New York 6, N.Y.) to final concentration $50 \mu \mathrm{g} . / \mathrm{ml}$. transformed heat-killed $\left(30 \mathrm{~min}\right.$. at $60^{\circ}$ ) Bacillus $\mathrm{M}$ suspensions into protoplasmic rodlike forms, free from cell wall, the 'small bacilli' of Welshimer \& Robinow (1949) and of Tomcsik \& Guex-Holzer (1952). Lysozyme $10 \mu \mathrm{g} . / \mathrm{ml}$. of the standard suspension in Ringer (living bacteria) gave after $30 \mathrm{~min}$. incubation forms which showed only a polar separation of cell wall from protoplasm (Pl. 1, fig. 5), when the activity of lyzozyme was stopped by $38 \%$ formaldehyde solution (1 volume of $38 \%$ formaldehyde to 5 vol. suspension). Protoplasts were obtained by longer treatment with lysozyme $(50 \mu \mathrm{g} . / \mathrm{ml}$. standard suspension of living bacteria). They were fixed in the same manner with formaldehyde.

Dry weight determinations. Samples (30-50 ml.) of standard bacterial suspension or of suspensions of the lysozyme-depolymerized forms were centrifuged in a MSE centrifuge at $5^{\circ}$ for $1 \mathrm{hr}$. at $3000 \mathrm{rev} . / \mathrm{min}$. (1760 RCF). The dry weight determination was made at $105^{\circ}$ for 5 to $6 \mathrm{hr}$., each determination was made in triplicate.

Nitrogen determination. A micro-Kjeldahl analysis of Bacillus $\mathrm{M}$ in triplicate gave a nitrogen content of $\mathbf{9 . 0 8} \%$ (dry weight $\%$, mean value).

Preparation of bacterial suspensions or of lysozyme-depolymerized forms for the Gram reaction. The suspensions were centrifuged, the absence of bacilli or of forms in the supernatant fluid was checked by microscopic examination. The sediments were resuspended in the equal volumes of deionized water. These suspensions were all at $\mathrm{pH}$ of $6 \cdot 1-6 \cdot 3$. This method of preparation permitted about the same numbers of bacilli and lysozyme-depolymerized forms in the same volume of suspension to be obtained.

Gram reaction. The reaction was performed after the method of Wensinck \& Boevé (1957) with some modifications; the counter-stain was omitted. (1) Crystal violet uptake. Kristallviolett E. Merck, Darmstadt, Germany, No. 1408, batch 136304 , dye content $85 \%$ was used for all experiments. A standard solution of $1 \mathrm{mg}$. dye in $1 \mathrm{ml}$. deionized water was prepared. A reference curve of the dye concentration was constructed with the Klett-Summerson colorimeter with filter 59, by using dilutions of the standard dye solution in Klett tubes (readings 60-600). The dye uptake was determined as follows: $1 \mathrm{ml}$. of standard dye solution (=1 $\mathrm{mg}$. dye) was added to different amounts ( 1 to $9 \mathrm{ml}$.) of suspension of bacilli or lysozymedepolymerized forms. The mixture was left for $10 \mathrm{~min}$. at room temperature and 
then centrifuged for $20 \mathrm{~min}$. at $3000 \mathrm{rev} . / \mathrm{min}$. The dye concentration of the supernatant fluid was determined in the Klett-Summerson colorimeter with filter 59. The difference between the dye content of the supernatant fluid and the initial $1 \mathrm{mg}$. dye of the $1 \mathrm{ml}$. dye standard solution gave the dye uptake.

(2) Washing step. The coloured deposits were resuspended in $5 \mathrm{ml}$. deionized water and then centrifuged for $30 \mathrm{~min}$. at $3000 \mathrm{rev} . / \mathrm{min}$. The dye content of the supernatant fluid was then measured.

(3) Iodine uptake. $1 \mathrm{~g}$. iodine (Iodum resublimatum pro analysi, Merck) and $2 \mathrm{~g}$. potassium iodate (Kalium iodatum pro analysi, Merck) were dissolved in $800 \mathrm{ml}$. deionized water. $5 \mathrm{ml}$. of this solution were added to the coloured and washed sediments of bacilli or cell forms. These suspensions were allowed to stand for $10 \mathrm{~min}$. at room temperature and were then centrifuged for $15 \mathrm{~min}$. at $3000 \mathrm{rev} . / \mathrm{min}$. The residual iodine in the supernatant fluid was titrated and iodine uptake determined by difference. Iodine titration was done with $\mathrm{N} / 200$ or $\mathrm{N} / 500 \mathrm{Na}_{2} \mathrm{~S}_{2} \mathrm{O}_{3}$ with starch indicator. Experiments have shown that $5 \mathrm{ml}$. of iodine solution is sufficient to provide excess of iodine with all suspensions used.

(4) Decolorization. Ethanol (95\% (v/v) in water; $5 \mathrm{ml}$.) was added to the deposits of bacilli or cell forms after the iodine step. The suspension was allowed to stand for $10 \mathrm{~min}$. and was then centrifuged for $20 \mathrm{~min}$. at $3000 \mathrm{rev} . / \mathrm{min}$. The resulting deposits were resuspended in $5 \mathrm{ml}$. ethanol $(95 \% \mathrm{v} / \mathrm{v})$ and centrifuged again for $15 \mathrm{~min}$. at $3000 \mathrm{rev} . / \mathrm{min}$. The dye content of the combined supernatant fluids was determined by the usual colorimetric method (see dye uptake) after adding 2 or 3 drops of concentrated $\mathrm{Na}_{2} \mathrm{~S}_{2} \mathrm{O}_{3}$ solution to the supernatant fluids (reduction of the iodine). Iodine of the supernatant fluids was determined by its titration with $\mathrm{N} / 500$ $\mathrm{Na}_{2} \mathrm{~S}_{2} \mathrm{O}_{3}$ on parallel samples. Because of the crystal violet in the supernatant fluids, the result of this titration was indicated only by a change of the colour of the supernatant fluid from purple to deep blue (blue colour of the dye). This change was only visible in daylight. Therefore this titration of iodine in ethanolic solution where starch was useless as indicator, did not give as good results as an ordinary iodine titration (variations up to $20 \%$ ).

Action of lysozyme upon stained cells of Bacillus м. Since lysozyme reacts only in solutions containing $\mathrm{Na}^{+}$the stained bacterial suspensions were centrifuged and the deposits resuspended in the same volume of Ringer solution. Lysozyme (1 mg./ ml. suspension) was then added.

\section{RESULTS}

\section{Gram reaction with untreated and lysozyme-treated Bacillus $\mathbf{M}$}

Crystal violet uptake. As shown in Fig. 1 treatment with lysozyme before staining decreased the subsequent dye uptake, and the organisms which show a polar separation of cell wall from protoplasm and which stain Gram negative on ordinary smears (Scherrer, 1961) take up less dye than intact organisms. Protoplasts and 'small bacilli' showed the smallest dye uptake. This is true whether dye uptake is compared on the basis of equal volumes of suspensions or on the basis of equal dry weight of suspended material.

As shown by Finkelstein \& Bartholomew (1953), the dye uptake depends on the ratio available dye:quantity of cells. Here, too, this ratio seems valid. The $1 \mathrm{ml}$. suspensions of Bacillus $\mathrm{M}$ or its lysozyme-treated forms give the largest dye uptake. 
and 2 in Pl. 1 will show. The capsule is stained at the highest dye uptakes, for negative staining of crystal violet stained bacteria indicate a slightly blue capsule (Pl. 1, fig. 3), although microscopic examination showed that the Indian ink had extracted much dye from the bacilli. A comparison of the cell dimensions between Pl. 1, fig. 1 and 3 (wet-mount preparation and negative staining) gives the same result. Air-dried smears of crystal violet stained cells showed partially coloured capsules (Pl. 1, fig. 4), but only at the highest dye uptake values. All lysozymedepolymerized forms showed a deeply blue protoplasm and a slightly blue cell wall (Pl. 1, fig. 5) in wet-mount preparations. Protoplasts and 'small bacilli' were both evenly stained blue.

Effect of washing after crystal violet. Washing the crystal violet stained sediments of the bacilli or the cell forms with deionized water removed a small amount of dye. It was usually not more than $1-5 \%$, except for the $1 \mathrm{ml}$. suspensions where it was
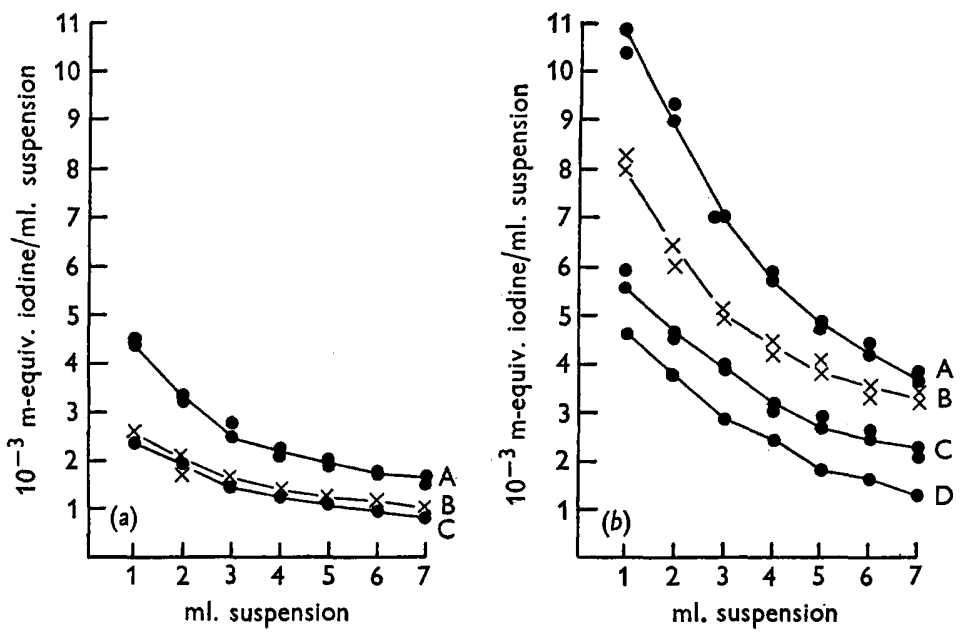

Fig. 2a, b. Iodine uptake of Bacillus M. Uptake of colourless cells (a) and cells stained with crystal violet $(b)$. A, Intact Bacillus $M\left(14^{*}\right) ; B$, forms with a polar separation of the cell wall from the protoplasm $\left(14^{*}\right)$; C, fixed protoplasts $\left(14^{*}\right)$; D, unfixed 'small bacilli' free from cell walls $\left(7^{*}\right) ; *$, number of determinations.

higher for the suspensions of intact bacilli. The dye loss was relatively higher for organisms which still possessed an intact cell wall than for all lysozyme-depolymerized forms. Microscopic examination showed that the capsule was no longer coloured after the washing step. No other changes were observed.

Iodine uptake. Wensinck \& Boevé (1957) and Scherrer (1963) showed that even colourless organisms take up some iodine. The iodine uptake depended on the ratio iodine: cells. Figure $2 a$ shows that the action of lysozyme decreased a subsequent iodine uptake by colourless organisms of Bacillus $\mathrm{M}$; all lysozyme-depolymerized forms took up less iodine than did intact organisms.

Crystal violet stained cells (Wensinck \& Boevé, 1957) take up much more iodine because of the formation of a dye iodine complex. Figure $2 b$ shows the iodine uptake of intact organisms and treated forms after the crystal violet uptake. Here, too, iodine uptake was highest for intact organisms, lower for forms with a polar separa- 
tion of cell wall from protoplasm, and lowest for protoplasts and 'small bacilli'. Extra iodine uptake depends on the previous crystal violet uptake (extra iodine $=$ total iodine uptake less iodine taken up by colourless cells). A plot of extra iodine uptake as a function of net crystal violet content (net content $=$ initial dye uptake less the dye extracted by the washing and iodine treatment steps) gives straight lines (Fig. 3). Therefore, as the proportions of the dye and iodine which intact organisms and lysozyme-depolymerized forms have taken up are the same, the dye iodine complex formed in the intact organism must be the same for all cell structures, cell wall and protoplasm. As there was a difference in the extra iodine uptake as between the intact organisms and protoplasts, the cell wall must take up some extra iodine for the formation of this same dye iodine complex.

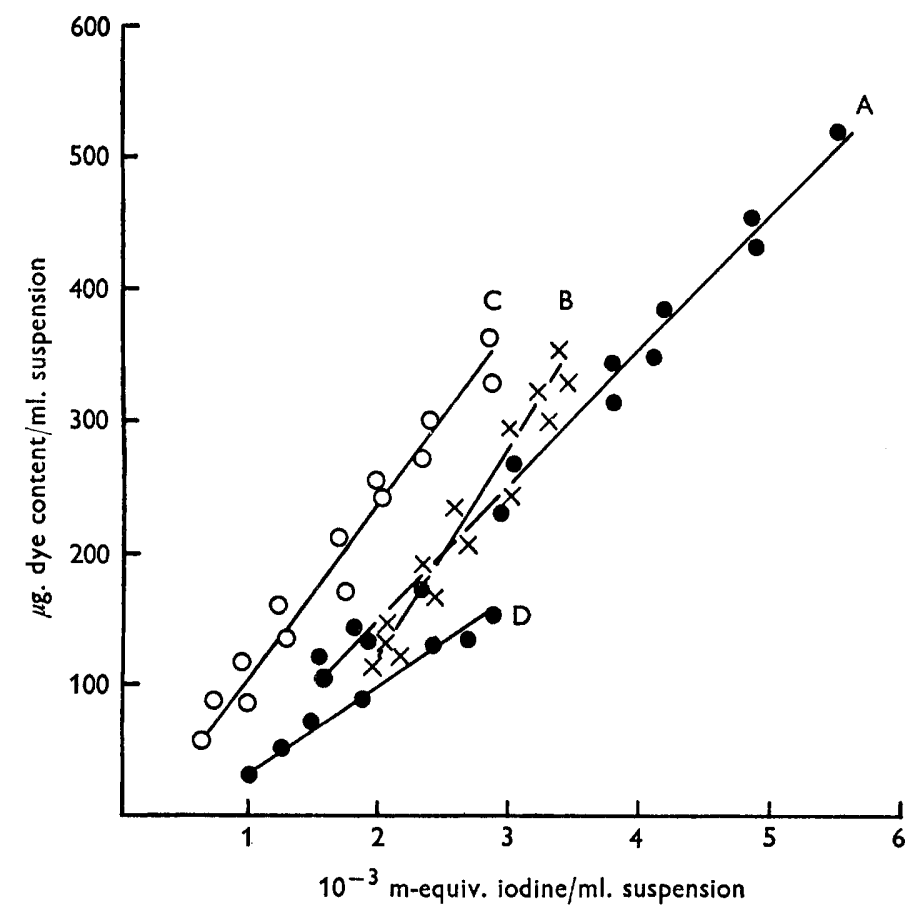

Fig. 3. Extra iodine uptake as in function of the net crystal violet content of Bacillus $M$. $A$, Intact Bacillus $M\left(14^{*}\right)$; $B$, forms with polar separation of cell wall from protoplasm $\left(14^{*}\right)$; C, fixed protoplasts $\left(14^{*}\right) ; D$, unfixed 'small bacilli' free of cell walls $\left(7^{*}\right) ; *$, number of determinations.

A small quantity of crystal violet was extracted by the iodine treatment, especially with bacteria which still possess their cell wall. Microscopic examinations of wet-mount preparations showed small droplet-like formations at the surface of the most deeply coloured organisms after the iodine step (Pl. 1, fig. 6). These formations were deep blue and were also seen at the cell walls of the forms which showed a polar separation of cell wall from protoplasm. Forms free from cell wall, such as protoplasts or 'small bacilli', did not show these droplets. This could lead to the hypothesis that they are due to interactions between dye and iodine at the cell surface, the cell wall or the capsule. 
Decolorization. The amount of crystal violet and iodine extracted by $95 \%(\mathrm{v} / \mathrm{v})$ ethanol from crystal violet and iodine stained bacilli or cell forms depended on the nature of the material: unfixed Bacillus $M$ suspensions gave up about $20-30 \%$ of their net crystal violet content, whereas formaldehyde-fixed organisms lost 30-45\% of their net dye content (Fig. 4a). The total quantity of dye extracted by ethanol was much larger for the cell forms which showed a polar separation of cell wall from protoplasm; it was about $80-90 \%$ of their net dye content. Protoplasts and 'small bacilli' lost about $80 \%$ of their net dye content. Cell wall preparations such as those described on p. 138 lost most, namely $90-95 \%$.
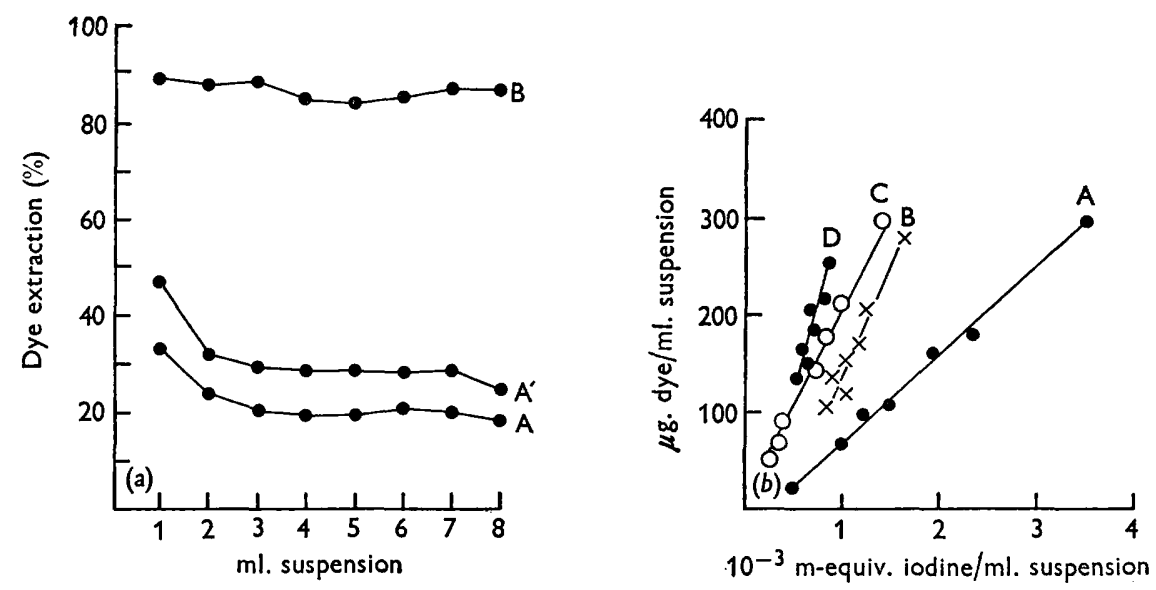

Fig. 4a, b. Crystal violet and iodine extraction of Bacillus m by $95 \%(v / v)$ ethanol. Dye extraction in \% of the net dye content $(a)$ and dye extraction as a function of the iodine extraction $(b)$. A, Unfixed Bacillus $\mathrm{M}\left(39^{*}\right)$; $\mathbf{A}^{\prime}$, formaldehyde-fixed Bacillus $\mathrm{M}\left(21^{*}\right)$; $B$, formaldehyde-fixed forms with polar separation of cell walls from protoplasm $\left(14^{*}\right)$; C, formaldehyde-fixed protoplasts $\left(7^{*}\right) ; D$, unfixed 'small bacilli' free from cell walls $\left(7^{*}\right)$; $*$, number of determinations. The curves indicate arithmetical mean values. Results of iodine titration in alcoholic solution varied about $20 \%$.

The dye loss of all lysozyme-depolymerized forms was about twice that of intact bacteria. All these lysozyme-treated forms were Gram negative on ordinary smears. They differed from the intact organisms only by having their cell walls more or less dissolved with lysozyme, which suggests that the partial dissolution of the wall must be responsible for the larger extraction of the dye.

The iodine loss of the decolorization step of this Gram staining depended on the loss of crystal violet (Fig. $4 b$ ), although even colourless cells lost a very small amount of iodine. The ratio dye loss : iodine loss was the same for intact organisms as for the uptake of dye and extra iodine (Fig. 3). Therefore the dye iodine complex extracted by ethanol must be the same as that originally formed in the cell. Lysozymetreated forms show other ratios. This may be due to the titration method of the iodine, for it seems unlikely that the extraction transforms this complex when the cell wall is no longer intact.

The colour of the different suspensions after decolorization depends on their dye content, as shown by microscopic and macroscopic examination: intact organisms 
were deeply blue while lysozyme-treated forms are white or colourless. Microscopic examination showed that all types of cell were smaller after the decolorization step (see Pl. 1, fig. 7).

\section{The action of lysozyme on Bacillus $\mathrm{M}$ during the different steps of the Gram stain}

The action of lysozyme on crystal violet stained cells. The addition of lysozyme to crystal violet stained organisms in Ringer solution did not give any measurable change in the dye content as compared with the control suspensions, although both lost much dye. The competition of the salt ions of the Ringer solution produces an extraction of the dye (McCalla, 1941). Microscopic examination showed, however, that lysozyme transformed the intact stained bacteria into forms free from cell wall. This transformation was much slower than with colourless bacteria and its result depended on the degree of dye uptake, i.e. only rodlike 'small bacilli' were formed at the highest dye uptake value and protoplasts only at the lowest dye value.
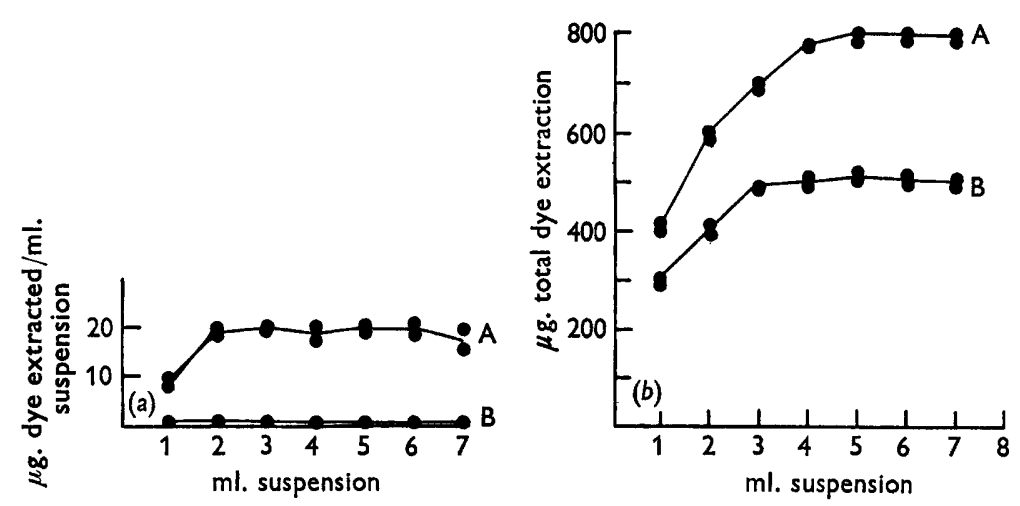

Fig. 5a, $b$. Influence of lysozyme on the Gram staining of Bacillus M. (a) Action of lysozyme $(4 \mathrm{hr}$.) on cells stained with crystal violet and iodine. Extraction of a small amount of dye. (b) Ethanolic extraction of the stained forms (crystal violet and iodine) obtained by the action of lysozyme. A, Bacillus $M$ treated with lysozyme (14*); B, control suspensions of stained Bacillus $M\left(14^{*}\right)$; *, number of determinations.

The action of lysozyme on iodine treated cells. The action of lysozyme on organisms which have been suspended in the iodine solution and were then resuspended in Ringer solution was much delayed, but gave the same forms as with crystal violet stained cells; namely, protoplasts at lowest iodine uptake, 'small bacilli' at highest iodine uptake. Iodine is known to inhibit the action of lysozyme (Thompson, 1941).

The action of lysozyme upon crystal violet and iodine stained bacilli. Lysozyme transformed these organisms into rodlike 'small bacilli' at all values of dye uptake. This transformation was very slow and did not release much crystal violet (Fig. 5a) The control suspensions did not give measurable amounts of dye. Figure $5 a$ shows that the dye loss caused by lysozyme was the same for all cell concentrations used (about $20 \mu \mathrm{g}$. dye/ml. suspension), except for the highest dye uptake level where the lysozyme did not entirely dissolve the cell wall (as seen by microscopic control). Iodine was found in all the supernatant fluids.

Therefore the cell wall contained small quantities of dye and iodine that were freed by lysozyme. An ethanol decolorization of the 'small bacilli' produced by 
lysozyme after the iodine step extracted a much larger amount of dye than with control suspensions (without lysozyme, Fig. $5 b$ ). The presence of the cell wall seems to inhibit the ethanol extraction of the dye iodine complex.

The action of lysozyme on Gram-stained organisms. Lysozyme reacted with Gramstained (crystal violet stained, iodine treated and ethanol extracted) Bacillus $\mathrm{M}$ and transformed them into rodlike 'small bacilli' free from cell wall much more quickly than it did after the iodine step of the Gram reaction. Lysozyme did not extract any amount of dye larger than from the control suspensions. Therefore the cell wall no longer contained dye or iodine after the decolorization step. An extra third ethanol extraction of these lysozyme-treated forms released much more dye into the supernatant fluids than in the control. Salton (1961) found the same effects of lysozyme upon Gram-stained organisms.

\section{DISCUSSION}

The crystal violet uptake of Bacillus $M$ is changed by the action of lysozyme, for neither comparisons of the same number of intact organisms and all its lysozymedepolymerized forms such as cells with a polar separation of the cell wall from the protoplasm, protoplasts, or 'small bacilli' free from cell wall, nor comparisons of the same weights of those cells and cell forms indicate the same dye uptake. The dye uptake of all forms is smaller than that of intact organisms. Therefore lysozyme must change the absorptive properties of the bacteria for crystal violet. Lysozyme depolymerizes the capsule and the cell wall of Bacillus M (Tomcsik \& Guex-Holzer, 1952). These cell structures, especially the cell wall, may play an important role in the dye absorption by bacteria. It is still under discussion whether Gram-positive and Gram-negative bacteria take up the same quantity of primary dye (Kennedy \& Barbaro, 1953; Bartholomew \& Finkelstein, 1954; Wensinck \& Boevé, 1957; Finkelstein \& Bartholomew, 1960). The present experiments show that forms which showed a polar separation of cell wall from protoplasm (Gram negative on ordinary smears) took up less dye than did intact organisms of Bacillus $\mathbf{M}$. This difference in dye uptake is only important for the most dilute bacterial suspensions where the ratio dye:organism is the highest; it is of no interest by comparison with the much larger extraction (decolorization) of dye iodine complex from these lysozymedepolymerized forms.

Wensinck \& Boevé (1957) showed that the iodine uptake depends on the previous dye uptake; dye and iodine form a complex, and this complex is the same in cell wall and in protoplasm. The present experiments indicate that this same complex is extracted from whole organisms by the ethanol decolorization. It may be supposed that the other proportions of dye and iodine which the decolorization step extracts from all lysozyme-depolymerized forms are due to the method of titration.

The dye uptake of the cell wall-that of the capsule does not matter for it is washed out easily-seems rather important after the dye uptake step, but the subsequent wash and iodine steps extract much dye from it.

The cell wall of Bacillus $\mathrm{m}$ does not play an important role for the content of the whole organism in dye or iodine, for the dissolution of cell wall by lysozyme after the iodine treatment of the Gram reaction does not free much dye iodine complex. Bartholomew \& Finkelstein (1958) showed that the staining of the cell wall region 
is not essential for the Gram positivity of fixed and Gram-treated bacteria. It is not the dye or iodine content of the cell wall that is important for the Gram positivity of the whole organism, but its chemical integrity. Partial or total dissolution of the cell wall by lysozyme before the Gram treatment as well as its destruction after the iodine step permit a much larger extraction of dye iodine complex and would give therefore Gram-negative organisms. Wensinck \& Boevé (1957) and Salton (1961) pointed out that changes induced by higher ethanol concentrations inhibit extraction of the dye iodine complex from Gram-positive cells. The present experiments have shown that the cell wall is responsible for this inhibition.

\section{REFERENCES}

Barbaro, J. F. \& Kennedy, E. R. (1954). A quantitative gram reaction. J. Bact. 67, 603.

Bartholomew, J. W. \& Finkelstein, H. (1954). Crystal violet binding capacity and the Gram reaction of bacterial cells. J. Bact. 67, 689.

Bartholomew, J. W. \& Finkelstein, H. (1958). Relationship of cell wall staining to Gram differentiation. J. Bact. 75, 77.

Finkelstein, H. \& Bartholomew, J. W. (1953). Quantitative determination of dye uptake by bacterial cells. Stain Technol. 28, 177.

Finkelstein, H. \& Bartholomew, J. W. (1960). Dye uptake by Gram-positive and Gram-negative cells as related to the adsorption laws. $J$. Bact. 80, 14.

Gerhardt, P., Vennes, J. \& Britt, E. M. (1956). Gram reactions of isolated protoplasts and surface membranes of Bacillus megaterium. J. Bact. 72, 721.

Kennedy, E. R. \& Barbaro, J. F. (1953). Quantitative absorption of crystal violet. J. Bact. 65, 678.

MCCALLA, T. M. (1941). The reactions of certain stains with bacteria. Stain Technol. 16, 27.

Petronelri, A. (1950). Modificazioni della colorabilità indotto dal lisozima su alcune specie microbiche. Boll. Ist. sieroter. Milano, 29, 252.

Salton, M. R. J. (1961). The anatomy of the bacterial surface. Bact. Rev. 25, 77.

ScherRer, R. (1961). Über den Mechanismus der Gramfärbung. Sitz der Gramreaktion bei Bacillus M. Path. et Microbiol. 24, 756.

ScherRer, R. (1963). Die Gramfärbung. Ergebn. Mikrobiol. 36, 59.

StÄhelin, H. (1953). Über sphärische Transformation der Milzbrandbazillen. Schweiz. Z. Path. 16, 892.

Thompson, R. (1941). Lysozyme and the antibacterial properties of tears. Arch. Ophthal., N.Y. 25, 491.

Toмcsık, J. (1950). Über eine bewegliche Mutante des Bacillus anthracis. Schreiz. Z. Path. 13, 616.

Toмcsıк, J. (1960). Ein Versuch zur Analyse eigener experimenteller Arbeiten. Basel: Benno Schwabe Co.

Tomcsik, J. \& Guex-Holzer, S. (1952). Änderung der Bakterienzelle im Verlaufe der Lysozymeinwirkung. Schweiz. Z. Path. 15, 517.

Welshimer, H. J. \& Robinow, C. F. (1949). The lysis of Bacillus megaterium by lysozyme. J. Bact. 57, 489.

Wensinck, F. \& BoevÉ, J. J. (1957). Quantitative analysis of the Gram reaction. J. gen. Microbiol. 17, 401. 
Journal of General Microbiology, Vol. 31, No. 1

Plate 1

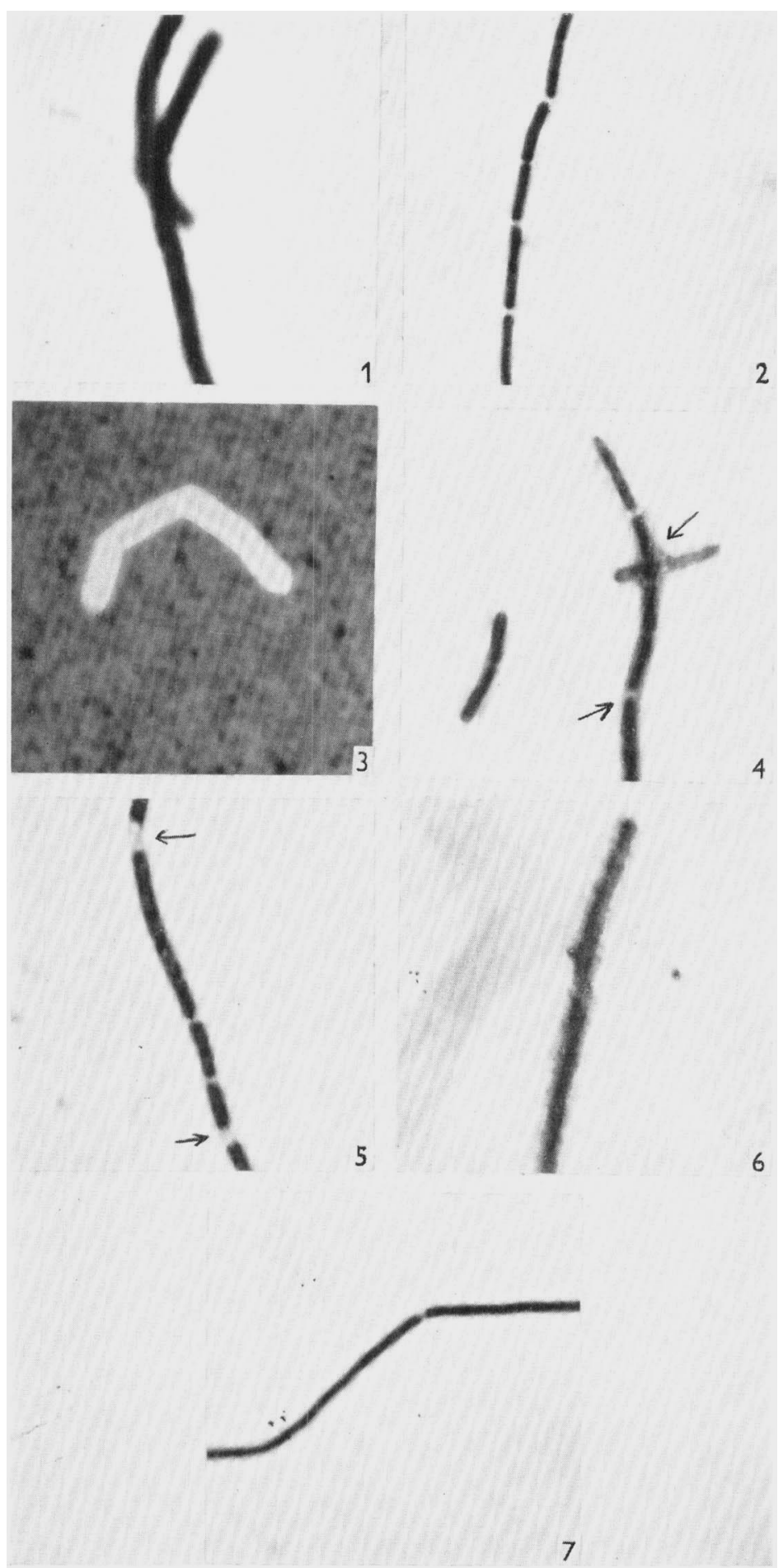

R. SCHERRER

(Facing p. 144) 



\section{EXPLANATION OF PLATE}

Gram stain of Bacillus $M$ in suspension. The magnification of all figures is 2000 . Figs. 1, 2, 3, 5, 6 and 7 are micrographs of wet mount preparations on slides ( 1 drop of suspension of stained bacteria was put on a slide, recovered with a coverslip and examined in ordinary microscope with oil-immersion). Fig. 4 is an air-dried preparation ( 1 drop of the bacterial suspension was put on a slide and examined in the same manner after air-drying).

Figs. 1 to 5. Crystal violet uptake of Bacillus $\mathbf{M .}$

Fig. 1. Cells after the uptake of $550 \mu \mathrm{g}$. dye/ml. suspension.

Fig. 2. The same, only after uptake of $200 \mu \mathrm{g}$. dye $/ \mathrm{ml}$.

Fig. 3. Negative staining of the bacilli in Fig. 1 with Indian ink. Note the capsules.

Fig. 4. The same as in Fig. 1, only air-dried preparation. Capsular staining (arrows).

Fig. 5. Lysozyme-depolymerized forms of Bacillus $\mathbf{m}$ with polar separation of cell wall from protoplasm. Forms with the highest value of dye uptake. Arrows : cross walls.

Fig. 6. Bacillus $M$ stained with crystal violet and iodine. Note the dropletlike formations at the cell surface.

Fig. 7. Gram-stained Bacillus $\mathbf{m}$ (counterstain omitted). 